Check for updates

Cite this: RSC Adv., 2019, 9, 30615

Received 12th July 2019

Accepted 19th September 2019

DOI: $10.1039 / c 9 r a 05332 h$

rsc.li/rsc-advances

\section{Accumulation risk and sources of heavy metals in supratidal wetlands along the west coast of the Bohai Sea†}

\author{
Fude Liu, (DD* Bowen Zheng, Yi Zheng, Xue Mo and Desheng Li
}

The heavy metals $\mathrm{Al}, \mathrm{Cr}, \mathrm{Cu}, \mathrm{Ni}, \mathrm{Pb}, \mathrm{Zn}, \mathrm{Fe}, \mathrm{Mn}, \mathrm{As}$, and $\mathrm{Cd}$ in the rainfall-driven supratidal wetlands along the west coast of the Bohai Sea (the areas are named site 1, site 2, site 3, and site 4 from south to north in the gradient in this study) are tested for their accumulation risks and sources. Results show that the distribution and enrichment of the heavy metals in the supratidal wetlands are lower in site 1 than in sites $2-4$. The risk indices (RIs) of all sites are less than 150, indicating low-moderate risk. However, the RI values are primarily dominated by the risk indices $\left(E_{r}^{i}\right)$ of $A s$ and $\mathrm{Cd}$. The accumulative contribution values of $E_{r}{ }^{i}-A s$ and $E_{r}{ }^{i}-\mathrm{Cd}$ in sites 1, 2, 3, and 4 are $79.05 \%, 77.80 \%, 80.54 \%$, and 76.43\%, respectively. Additionally, the contamination degree $\left(C_{d}\right)$ and the Nemero comprehensive pollution index (PN) of the supratidal wetland in site 1 are 6.86 and 0.74 respectively, indicating a low-risk state. By contrast, the $C_{d}$ and PN values of the other three supratidal wetlands are higher than those of site 1, suggesting an increasing accumulation risk for heavy metals in sites 2, 3 and 4. Our analysis indicates that the heavy metals $\mathrm{Al}, \mathrm{Cr}, \mathrm{Mn}$, and $\mathrm{Fe}$ in all the supratidal wetlands mainly originate from the weathering of rocks and their parent materials. $\mathrm{Pb}$ is significantly correlated with anthropogenic activities, while $\mathrm{Cu}, \mathrm{As}$, and $\mathrm{Cd}$ are likely induced by anthropogenic activities and atmospheric deposition. The sources of $\mathrm{Ni}$ and $\mathrm{Zn}$ should be determined on the basis of the situation of the wetland and its surrounding areas. For example, Ni is mainly affected by anthropogenic activities in site 2, whereas the origins of $\mathrm{Ni}$ are soil parent materials or atmospheric depositions in sites 1,3 , and 4 . Our results can provide data to support the utilization strategy and sustainable development plans for marine space resources on the coast of the Bohai Sea.

\section{Introduction}

Heavy metal pollution has widely attracted special attention from scientists and environmentalists, ${ }^{\mathbf{1 , 2}}$ mainly because such metals are easily accumulated by organisms, are gradually enriched and magnified along the food chains of ecosystems, and ultimately threaten human health. ${ }^{3-5}$ Heavy metals in soil are often considered a powerful indicator of the effects of human activities given that the origins of heavy metal pollution in the environment are primarily anthropogenic types. ${ }^{6}$

Coastal wetlands generally lie between terrestrial and marine ecosystems and often act as natural filters in removing chemicals and contaminants from surface runoff or river water. ${ }^{7}$ Wetland soils have an important role in transferring chemical contaminants, including organic pollutants and heavy metals, through the physicochemical processes of adsorption, ligand exchange, and sedimentation. ${ }^{8}$ Heavy metals in wetland soils

Tianjin Key Laboratory of Hazardous Waste Safety Disposal and Recycling Technology, School of Environmental Science and Safety Engineering, Tianjin University of Technology, Tianjin 300384, China. E-mail: fudeliu2005@163.com

$\dagger$ Electronic supplementary information (ESI) available. See DOI: 10.1039/c9ra05332h are mainly determined by their chemical forms and their binding states, and the accumulation, mobility, and toxicity of these heavy metals affect both soils and organisms. ${ }^{9}$ Moreover, the migration and enrichment of heavy metals are affected by soil physicochemical properties, such as $\mathrm{pH}$, soil organic matter (SOM), temperature, and salinity, among others, and they subsequently affect the mobility of heavy metals, further influencing their accumulation in soils., ${ }^{\mathbf{1 1 0 , 1 1}}$ Heavy metals are nonbiodegradable or refractory pollutants and can persist in the ecosystem for a long time. ${ }^{12}$ Once a certain amount of heavy metals is accumulated in plant tissues, the growth or survival of plants becomes adversely affected, and the wetland ecosystems become unstable. ${ }^{\mathbf{1 3 , 1 4}}$ In addition, heavy metals in litter or rotted leaves usually increase in concentration during decomposition and can continue to be deposited in the sediment or transported by water flow to estuarine and coasts, ${ }^{15}$ which then increase the pollution risk of these areas.

Heavy metal pollution has become increasingly serious in the past two decades due to various urbanization activities in coastal areas, such as the rapid industrial development of many large river deltas. ${ }^{1}$ As for the impact of industrial activities on the accumulation of heavy metals in wetlands, researchers believe that wetland reclamation may lead to the increase in 
metal contents in soil. ${ }^{\mathbf{1 6 - 1 8}}$ Other researchers have also suggested that agriculture and aquaculture can increase heavy metal content (e.g., Cd) in lagoon sediments. ${ }^{19}$ Studies have also shown that traffic can lead to high deposits of heavy metals in roadside soil. ${ }^{20}$ The flow-sediment regulation regime of Yellow River has reportedly increased the content of some heavy metals in the estuarine and intertidal wetlands. ${ }^{21}$ Therefore, a comprehensive understanding of the dynamic changes, sources, and input pathways of heavy metals can help build a sustainable utilization strategy for marine space resources and promote the harmonious development of human and nature.

The coastal region of Bohai Sea, which is one of the most active areas in China, has been subjected to considerable environmental pressure due to its dense population and high agricultural, aquaculture, urban construction activities. The categories of heavy metals and their input pathways vary depending on the types of human activities, but an information gap has considerably limited our understanding of the sources and accumulation risk of heavy metals in certain habitats. Studies on heavy metal pollution have been carried out for some coastal wetlands, ${ }^{\mathbf{1 , 2 2 2 , 2 3}}$ but the research on heavy metals in rainfall-driven supratidal wetlands remains to be rare. As we all known, the community in the supratidal habitat often experiences long dry periods and then becomes waterlogged following heavy rainfall. ${ }^{24}$ Thus, rainfall-driven wetland is often observed in the supratidal zone of Northern China, and its hydrologic regime mainly depends on rainfall events in wet seasons. ${ }^{25}$ Compared with intertidal wetlands and offshore waters, rainfall-driven supratidal wetlands are more easily disturbed by human activities. This differentiation poses a challenge in investigating the accumulation risk and sources of heavy metals in supratidal wetlands.

The heavy metals of $\mathrm{Al}, \mathrm{Cr}, \mathrm{Cu}, \mathrm{Ni}, \mathrm{Pb}, \mathrm{Zn}, \mathrm{Fe}, \mathrm{Mn}$, As, and $\mathrm{Cd}$ in the rainfall-driven supratidal wetlands along the west coast of Bohai Sea are tested in this study. The objectives of our study are as follows: (a) learn the distribution and enrichment characteristics of the above mentioned heavy metals in the rainfalldriven supratidal wetlands of Bohai Sea; (b) evaluate the accumulation risk of the heavy metals in the rainfall-driven supratidal wetlands of Bohai Sea; and (c) explore the sources and input pathways of the heavy metals in the different rainfalldriven supratidal wetlands of Bohai Sea.

\section{Materials and methods}

\subsection{Site description}

The sites selected for the present study are located along the west coast of Bohai Sea. Bohai Sea, the largest semi-enclosed marginal sea along the continental shelf of China, is mainly composed of Liaodong Bay, Bohai Bay, Laizhou Bay, and the central basin. The major rivers along the coast of Bohai Sea are as follows: Yellow River, Liaohe River, Luanhe River, Haihe River, Jiyunhe River, and Xiaoqinghe River. These rivers carry $1.3 \times 10^{9} \mathrm{t}$ of sediments into the sea each year, particularly by Yellow River $\left(1.2 \times 10^{9} \mathrm{t}\right)$, Haihe River $\left(7.0 \times 10^{7} \mathrm{t}\right)$, Liaohe River $\left(5.5 \times 10^{7} \mathrm{t}\right)$, and Luanhe River $\left(2.4 \times 10^{7} \mathrm{t}\right) \cdot{ }^{26}$ Apart from transporting large volumes of sediments to the sea, the rivers also carry environmental pollutants to the offshore waters and coastal wetlands. For example, heavy metals pollutants enter the rivers via surface runoff and then flow to Bohai Sea. In addition, the region around Bohai Sea has one of the densest populations with the highest social and economic development levels in China. However, the rapid economic development of the region has led to environmental problems, and pollution due to heavy metals in the coastal habitats and offshore waters is currently a major environmental issue.

In this study, four study sites in the supratidal regions along the west coast of Bohai Sea are selected. The sites are named site 1, site 2 , site 3 , and site 4 from south to north in the gradient shown in Fig. 1. The study area includes two of the three bays (Bohai Bay and Laizhou Bay) of Bohai Sea. The number and types of coastal wetlands in the study area are large and diverse, respectively.

The first study site (site 1) is located in the coastal supratidal wetland of Weifang, Shandong Province. All sampling sites (E: $119^{\circ} 22^{\prime}-119^{\circ} 46^{\prime}$; N: $37^{\circ} 03^{\prime}-38^{\circ} 07^{\prime}$ ) lie within the experimental area of the Changyi Marine Ecology Special Reserve, which is the only national reserve for Tamarix chinensis protection in China. Site 1 has a warm and semi-humid continental monsoon climate. The average annual temperature is approximately $12.9{ }^{\circ} \mathrm{C}$, the average annual rainfall is $580-660 \mathrm{~mm}$, and the average annual evaporation is $1764-1859 \mathrm{~mm}$. The soil type is coastal solonchak, and the vegetation types are mainly shrubs and herbs. According to our investigation of site 1, the dominant shrub species are Tamarix chinensis, and the dominant herbaceous plants are Artemisia capillaries, Phragmites australis, and Setaria viridis.

The second study site (site 2) is located in the coastal supratidal wetland of Dongying, Shandong Province. All sampling sites (E: $118^{\circ} 15^{\prime}-119^{\circ} 19^{\prime}$; N: $\left.37^{\circ} 24^{\prime}-38^{\circ} 10^{\prime}\right)$ lie within the experimental area of Yellow River Delta National Nature Reserve. Site 2 is characterized by a warm and semi-humid continental monsoon climate with an average annual temperature of $12.8{ }^{\circ} \mathrm{C}$, an average annual precipitation of $556 \mathrm{~mm}$, and an average annual evaporation of $1885 \mathrm{~mm}$. The soil type is coastal solonchak, and the vegetation type is a meadow landscape. Annual and perennial herbs are dominant, whereas woody plants are rare. Suaeda salsa, Phragmites australis, and Tamarix chinensis have high frequencies of occurrence in site 2.

The third study site (site 3 ) is located in the coastal supratidal wetland of Binzhou, Shandong Province. All sampling sites (E: $117^{\circ} 50^{\prime}-118^{\circ} 00^{\prime} ; \mathrm{N}: 38^{\circ} 13^{\prime}-39^{\circ} 00^{\prime}$ ) lie within the experimental area of Shell Island and Wetland National Nature Reserve. The climate of site 3 is north temperate continental monsoon. The average annual temperature is $12.0{ }^{\circ} \mathrm{C}$, the average annual precipitation is $575.4 \mathrm{~mm}$, and the average annual evaporation is $1213.5 \mathrm{~mm}$. The soil type is coastal solonchak. According to our survey, Artemisia carvifolia, Phragmites australis, Cynanchum chinense, Caragana korshinskii, and Suaeda salsa are the most popular species in site 3 .

The fourth study site (site 4 ) is located in the coastal supratidal wetland of Tianjin. All sampling sites (E: $117^{\circ} 30^{\prime}-$ $117^{\circ} 47^{\prime}$; N: $38^{\circ} 44^{\prime}-39^{\circ} 13^{\prime}$ ) lie within the estuarine region of Yongdingxin River in the Binhai New Area. Tianjin has a warm 


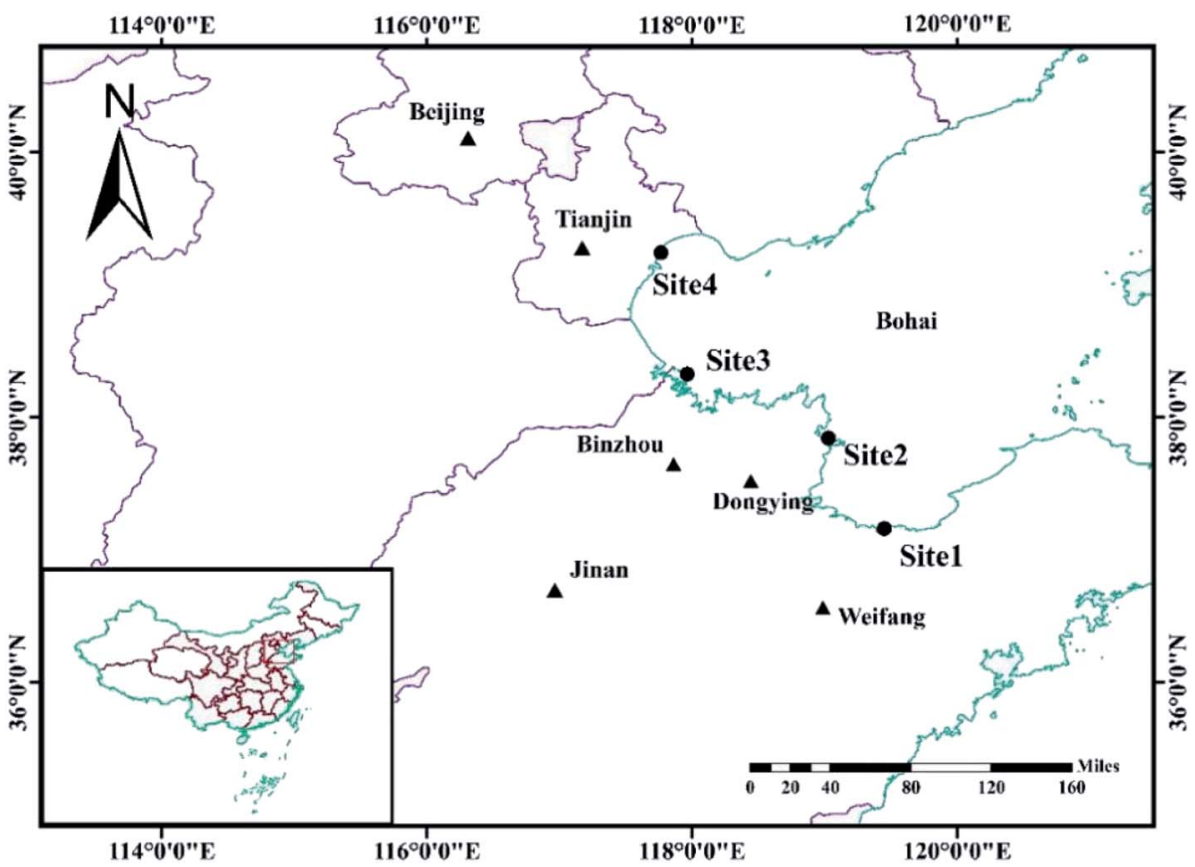

Fig. 1 Map of the coast of Bohai Sea and the location of our study sites. Cities are indicated by triangles, study sites are indicated by dots.

temperate monsoon continental climate with marine climatic characteristics. The average annual temperature is $13.3^{\circ} \mathrm{C}$, the average annual precipitation is $566.0 \mathrm{~mm}$, and the average annual evaporation is $1500 \mathrm{~mm}$. The soil type is coastal solonchak. The most popular herbaceous plants based on the plot survey of site 4 are Suaeda salsa, Setaria viridis, Phragmites australis, and Salsola collina, and the woody plant is mainly Tamarix chinensis.

\subsection{Sampling collection}

Samples were collected from the four study sites on August 2014 and August 2015. The seasonal variations of the annual and monthly precipitations are shown in Fig. 2, which can provide the information for waterlogging frequency, duration and water depth in those rainfall-driven wetlands. In this study, each site is equipped with two sampling strips perpendicular to the coastline, the distance between the two sampling points in each strip is $50 \mathrm{~m}$, and a quadrat of $3 \mathrm{~m} \times 3 \mathrm{~m}$ was performed in each point. Ten to twenty quadrats were set randomly in each study site based on the situation on the field. In particular, 20, 14, 10, and 20 quadrats were plotted in the supratidal wetlands of sites 1, 2, 3 , and 4 , respectively. The species names and the number of plants were investigated and recorded for each quadrat. Then, soil samples at depths of 0-10, 10-20, and 20-30 cm were collected randomly from five points in a quadrat. Samples of the same layers in each quadrat were mixed and placed inside polyethylene bags and brought to the laboratory for air drying. In this study, a total of $60,42,30$ and 60 soil samples were collected from sites 1, 2, 3 and 4, respectively. All dried soil samples were ground into fine powder and passed through a $0.149 \mathrm{~mm}$ nylon sieve and then sealed in plastic bottles for chemical analysis.
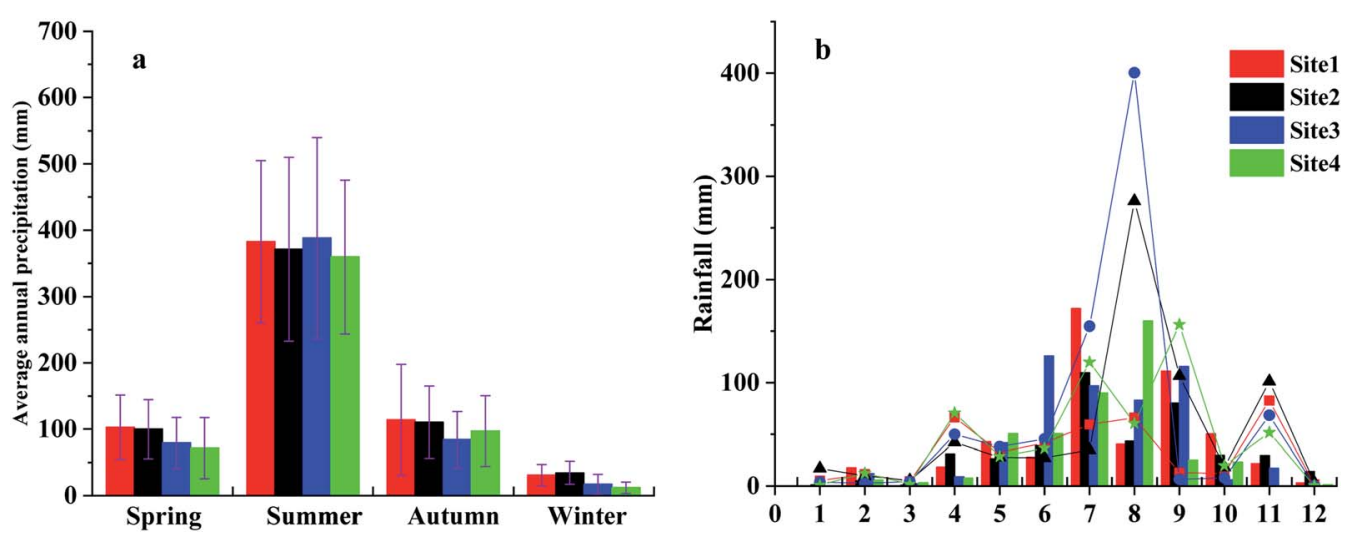

Fig. 2 Seasonal and monthly variation of mean annual precipitation along the west coast of Bohai Sea. (a) Seasonal variation of mean annual precipitation; (b) monthly variation of mean annual precipitation in sampling year (histogram indicates 2014, line indicates 2015). 


\subsection{Chemical analysis}

In this study, each soil sample was digested with $9 \mathrm{ml} \mathrm{H}_{2} \mathrm{SO}_{4}$ and $1 \mathrm{ml} \mathrm{HF}$, then was dissolved by microwave assisted digestion at $160{ }^{\circ} \mathrm{C}$ for two hours. Finally, the digested solution was adjusted to $25 \mathrm{ml}$ in a volumetric flask for trace elements measurement. Here, an inductively coupled plasma-optical emission spectrometry (ICP-OES, Varian, USA) was performed to analyze the concentrations of $\mathrm{Al}, \mathrm{Cr}, \mathrm{Cu}, \mathrm{Ni}, \mathrm{Pb}, \mathrm{Zn}, \mathrm{Fe}, \mathrm{Mn}$, As, and soil phosphorus (P). Quality assurance (QA) and quality control (QC) were estimated using duplicates, method blanks and national standard reference materials (GSB 04-1767-2004). During measurement, at least one control sample was spiked with each set of samples ( 1 bank for each 10 samples), and each measurement was replicated three times. The test results were reliable if the repeat sample analysis error was below $5 \% .{ }^{23}$ Atomic absorption spectroscopy was conducted to test the concentration of $\mathrm{Cd}$ in the soils. In this experiment, SOM was measured by the potassium dichromate titration method. ${ }^{27}$ Soil nitrogen $(\mathrm{N})$ concentration was analyzed by an elemental analyzer (2400II CHNS/O Elemental Analyzer, PerkinElmer, USA). Soil pH was measured by the potentiometric method at the soil-water ratio of $1: 2.5$ (IQ-150 Conductivity Analyzer, Germany). Salinity was measured by the weighing method at the soil-water ratio of $1: 5$. All measurements were repeated thrice to avoid systematic errors, and the arithmetic mean values were used for subsequent data analysis. The physicochemical properties of the soil samples are listed in Table 1 . The background values of the heavy metals of $\mathrm{Al}, \mathrm{Cr}, \mathrm{Cu}, \mathrm{Ni}, \mathrm{Pb}, \mathrm{Zn}, \mathrm{Fe}, \mathrm{Mn}, \mathrm{Cu}$, As, and Cd in Shandong are $66.2 \mathrm{~g} \mathrm{~kg}^{-1}, 66 \mathrm{mg} \mathrm{kg}{ }^{-1}, 24 \mathrm{mg}$ $\mathrm{kg}^{-1}, 25.8 \mathrm{mg} \mathrm{kg}{ }^{-1}, 25.8 \mathrm{mg} \mathrm{kg}{ }^{-1}, 63.5 \mathrm{mg} \mathrm{kg}^{-1}, 26.9 \mathrm{~g} \mathrm{~kg}^{-1}$, $644 \mathrm{mg} \mathrm{kg}^{-1}$, $9.3 \mathrm{mg} \mathrm{kg}^{-1}$, and $0.084 \mathrm{mg} \mathrm{kg}^{-1}$, respectively; as for Tianjin, the background values are $73.2 \mathrm{~g} \mathrm{~kg}^{-1}, 84.2 \mathrm{mg}$ $\mathrm{kg}^{-1}, 28.8 \mathrm{mg} \mathrm{kg}^{-1}, 33.3 \mathrm{mg} \mathrm{kg}{ }^{-1}, 21.0 \mathrm{mg} \mathrm{kg}{ }^{-1}, 79.3 \mathrm{mg} \mathrm{kg}^{-1}$, $33.5 \mathrm{~g} \mathrm{~kg}^{-1}, 686 \mathrm{mg} \mathrm{kg}^{-1}, 9.6 \mathrm{mg} \mathrm{kg}^{-1}$ and $0.09 \mathrm{mg} \mathrm{kg}^{-1} .{ }^{28}$

\subsection{Enrichment factor}

The enrichment factors (EFs) of heavy metals can be calculated by the following formulation:

$$
\mathrm{EF}=\frac{\left(\frac{C_{\mathrm{M}}}{C_{\mathrm{R}}}\right) \text { sample }}{\left(\frac{C_{\mathrm{M}}}{C_{\mathrm{R}}}\right) \text { background }}
$$

where $\frac{C_{\mathrm{M}}}{C_{\mathrm{R}}}$ is the ratio of measured and reference metals of the soil samples and their corresponding background values. In the present work, Al was selected as a reference metal to assess heavy metals ( $\mathrm{Cr}, \mathrm{Cu}, \mathrm{Ni}, \mathrm{Pb}, \mathrm{Zn}, \mathrm{Fe}, \mathrm{Mn}, \mathrm{Cu}, \mathrm{As}$, and $\mathrm{Cd}$ ) contamination in soil samples., ${ }^{2,23}$ While $\mathrm{Mn}$ was used as the reference metal for the calculation of EF-Al. ${ }^{29}$ Contamination can be classified on the basis of the following EF values: $\mathrm{EF}<2$, minor enrichment; $2 \leq \mathrm{EF}<5$, moderate enrichment; $5 \leq \mathrm{EF}<$ 20, moderately severe enrichment; $20 \leq \mathrm{EF}<40$, severe enrichment; and $\mathrm{EF} \geq 40$, extremely severe enrichment. ${ }^{30}$

\subsection{Risk index}

Ecological risk index (RI) can be estimated by the following equation:

$$
\mathrm{RI}=\sum_{i=1}^{m} E_{\mathrm{r}}{ }^{i}=\sum_{i=1}^{m} T_{\mathrm{r}}{ }^{i} \times C_{\mathrm{r}}{ }^{i}=\sum_{i=1}^{m} T_{\mathrm{r}}{ }^{i} \times \frac{C^{\mathrm{i}}}{{C_{n}}^{\mathrm{i}}}
$$

where $E_{\mathrm{r}}{ }^{i}$ is the potential ecological risk of a single heavy metal, and $T_{\mathrm{r}}{ }^{i}$ is the toxic-response factor of the heavy metal, as suggested by Hakanson et al. ${ }^{31}$ In the present work, the $T_{\mathrm{r}}{ }^{i}$ values of the heavy metals of $\mathrm{Al}, \mathrm{Cr}, \mathrm{Cu}, \mathrm{Ni}, \mathrm{Pb}, \mathrm{Zn}, \mathrm{Fe}, \mathrm{Mn}, \mathrm{Cu}, \mathrm{As}$, and $\mathrm{Cd}$ were $1,2,5,5,5,1,1,1,10$, and 30 , respectively. In eqn (2), $C^{i}$ denotes the measured concentration of the $i$-th heavy metal in the soil sample, and $C_{n}{ }^{i}$ denotes the background value of the $i$ th heavy metal. Contamination can be classified on the basis of the following RI values: RI < 150, low ecological risk; $150 \leq \mathrm{RI}<$ 300 , moderate ecological risk; $300 \leq \mathrm{RI}<600$, considerate ecological risk; and $\mathrm{RI} \geq 600$, high ecological risk.

\subsection{Degree of contamination}

Degree of contamination $\left(C_{\mathrm{d}}\right)$ can be calculated by the following equation: ${ }^{31}$

$$
\begin{gathered}
C_{\mathrm{d}}=\sum_{i=1}^{m} \mathrm{CF} \\
\mathrm{CF}=\frac{C^{i}}{C_{n}{ }^{i}}
\end{gathered}
$$

where $C^{i}$ is the measured concentration of the i-th heavy metal in the soil sample (in $\mathrm{mg} \mathrm{kg}^{-1}$ ), and $\mathrm{C}_{n}{ }^{i}$ is the background value of the i-th heavy metal (in $\mathrm{mg} \mathrm{kg}^{-1}$ ). Contamination can be classified on the basis of the following $C_{\mathrm{d}}$ values: $C_{\mathrm{d}} \leq 8$, low risk; $8<C_{\mathrm{d}} \leq 16$, moderate risk; $16<C_{\mathrm{d}} \leq 32$, considerate risk; and $C_{\mathrm{d}}>32$, high ecological risk.

\subsection{Nemero comprehensive pollution index}

In order to quantify the degree of heavy metals contamination, the Nemero comprehensive pollution index (PN) method was used in this study. Its formula is:

Table 1 Soil physicochemical properties in the four supratial wetlands along the west coast of Bohai Sea

\begin{tabular}{lrrrr}
\hline Study site & SOM $\left(\mathrm{g} \mathrm{kg}^{-1}\right)$ & $\mathrm{P}\left(\mathrm{mg} \mathrm{g}^{-1}\right)$ & $\mathrm{pH}$ & $\mathrm{Salt}(\%)$ \\
\hline Site 1 & $9.21 \pm 0.60$ & $0.38 \pm 0.11$ & $8.31 \pm 0.35$ & $1.16 \pm 0.53$ \\
Site 2 & $5.10 \pm 1.23$ & $0.53 \pm 0.03$ & $8.23 \pm 0.11$ & $5.68 \pm 2.41$ \\
Site 3 & $9.25 \pm 1.62$ & $0.45 \pm 0.14$ & $8.53 \pm 0.12$ & $6.07 \pm 1.49$ \\
Site 4 & $12.44 \pm 6.01$ & $0.49 \pm 0.02$ & $8.11 \pm 0.20$ & $1.95 \pm 0.47$
\end{tabular}




$$
\mathrm{PN}=\sqrt{\frac{\left(\frac{C_{i}}{S_{i}}\right)_{\max }^{2}+\left(\frac{1}{n} \sum_{i=1}^{m} \frac{C_{i}}{S_{i}}\right)^{2}}{2}},
$$

where $\mathrm{PN}$ is the synthesis evaluation score, $C_{i}$ is the measured content of the $i$-th element at a sampling point, and $S_{i}$ is the evaluation criterion of the $i$-th element. In this study, the evaluation criterion is based on the China Environmental Quality Standard for soil metals (GB15618-2018) ( $\mathrm{pH}>7.5$ ), Among them, $\mathrm{Al}, \mathrm{Fe}$ and $\mathrm{Mn}$ are evaluated by the background values of territorial soil elements (Al, Fe and Mn are not specified in GB156182018). The $\mathrm{PN}$ value was graded into five categories: $:^{32} \mathrm{PN} \leq 0.7$, safety; $0.7<\mathrm{PN} \leq 1.0$, guard; $1.0<\mathrm{PN} \leq 2.0$, low pollution; $2.0<$ $\mathrm{PN} \leq 3.0$, moderate pollution; and $\mathrm{PN}>3.0$, severe pollution.

\subsection{Data analysis}

One-way ANOVA was used to test the differences of the heavy metals and the other soil properties from the four study sites. Multiple-comparison tests were carried out. In particular, the Games-Howell method (Levene's test) was performed for variances assumed to be heterogeneous, while the Tukey's method was carried out for homogeneous variances. Spearman's correlation analysis was used to test the relationships between the physicochemical characteristics of the soil samples and the heavy metals. Correlation coefficients were depicted as bar graphs. Principal component analysis (PCA) was performed for the concentrations of all heavy metals and the physicochemical properties of the soil samples (salinity, $\mathrm{pH}$, soil $\mathrm{N}$, soil $\mathrm{P}$, and SOM). PCA was also performed to identify the main sources of the heavy metals, which then can explain the behavior and input pathways of these heavy metals in the supratidal wetlands of Bohai Sea. All statistical analyses in this study were conducted with SPSS 21.0 for Windows, and all figures were constructed by the Origin 8.5 software.

\section{Result and discussion}

\subsection{Distribution of heavy metals}

The mean concentrations of $\mathrm{Al}, \mathrm{Cr}, \mathrm{Cu}, \mathrm{Fe}$, and $\mathrm{Mn}$ are lower than their local background values (Fig. 3a-c, g and h), implying the absence of enrichment of these heavy metals in the coastal sediments of Bohai Sea. The mean concentration of Ni $(40.91 \mathrm{mg}$ $\mathrm{kg}^{-1}$ ) in the supratidal wetland of site 2 is higher than its local background value (Fig. 3d), which indicates that Ni concentration in this particular habitat may have been affected by other external factors. Wen et al. ${ }^{33}$ have reported a similar result (i.e., Ni with a mean concentration of $44.9 \mathrm{mg} \mathrm{kg}^{-1}$ ) for the same region of the Yellow River Delta. By contrast, the concentrations of $\mathrm{Ni}$ in the supratidal wetlands of sites 1,3 , and 4 are lower than their local background values (Fig. 3d). The concentrations of $\mathrm{Pb}$ in the supratidal wetlands of sites 1 and 2 are lower than their local background values, whereas those of sites 3 and 4 (mean values of $30.43 \mathrm{mg} \mathrm{kg}^{-1}$ and $21.04 \mathrm{mg} \mathrm{kg}^{-1}$, respectively) are significantly higher than their local background values (Fig. 3e). The findings indicate that $\mathrm{Pb}$ in these habitats has not originated from pedogenic weathering and instead may have stemmed from anthropogenic activities. The result of the present study is supported by the findings of Zhang et al. ${ }^{5}$ and Wen et al. ${ }^{33}$ who analyzed Shell Bay (site 3) and Yongdingxin River Watershed (site 4). In those studies, the mean values of $\mathrm{Pb}$ were as high as $34.4 \mathrm{mg} \mathrm{kg}^{-1}$ for Shell Bay and $38.5 \mathrm{mg} \mathrm{kg}^{-1}$ for the Yongdingxin River Watershed, the reported values are higher than the local background values in this study.

The mean concentrations of $\mathrm{Zn}$ in the supratidal wetlands of sites 2,3 , and 4 are $66.94 \mathrm{mg} \mathrm{kg}^{-1}, 75.12 \mathrm{mg} \mathrm{kg}^{-1}, 108.13 \mathrm{mg}$ $\mathrm{kg}^{-1}$, respectively (Fig. 3f), which are higher than their background values. This finding suggests that the $\mathrm{Zn}$ concentrations in these habitats are influenced by anthropogenic activities. By contrast, the concentration of $\mathrm{Zn}$ in the supratidal wetland of site 1 is lower than its local background value (Fig. 3f). Notably, previous studies ${ }^{5,23-35}$ have consistently reported that $\mathrm{Zn}$ concentrations are higher than their local background values in the coastal areas of Bohai Sea. The enrichment of $\mathrm{Zn}$ seems to be higher in Bohai Bay than in Laizhou Bay.

The mean concentrations in the supratidal wetlands of sites 1 , 2, 3, and 4 are $12.98 \mathrm{mg} \mathrm{kg}^{-1}, 21.43 \mathrm{mg} \mathrm{kg}^{-1}, 27.46 \mathrm{mg} \mathrm{kg}^{-1}$, and $24.39 \mathrm{mg} \mathrm{kg}^{-1}$ for As and $0.087 \mathrm{mg} \mathrm{kg}^{-1}, 0.14 \mathrm{mg} \mathrm{kg}^{-1}, 0.14 \mathrm{mg}$ $\mathrm{kg}^{-1}$, and $0.11 \mathrm{mg} \mathrm{kg}^{-1}$ for Cd (Fig. $3 \mathrm{i}$ and j), respectively. As and Cd have been proven to be the major heavy metal pollutants in previous case studies. ${ }^{2,23,36}$ In the present research, the concentrations of As and Cd are higher than their local background values, which suggest that As and Cd are highly affected by external sources (i.e., anthropogenic activities and atmospheric deposition).

\subsection{Assessment of heavy-metal potential ecological risk}

EF values are generally used to evaluate the external input of heavy metal in soils. ${ }^{37}$ Our results show that the EF values of $\mathrm{Al}$, $\mathrm{Fe}$, and $\mathrm{Mn}$ in all four sites are less than 2, which suggest that these heavy metals have not been contaminated. $38.10 \%$ and 92.86\% of EF-Cr and EF-Ni in the supratidal wetland of site 2 are greater than 2 (Fig. 4), indicating a certain degree of accumulation of $\mathrm{Cr}$ and $\mathrm{Ni}$ and their potential risks in the habitat. By contrast, the $\mathrm{EF}$ values of $\mathrm{Cr}$ and $\mathrm{Ni}$ in the supratidal wetlands of sites 1,3 , and 4 are all less than 2, indicating minimal enrichment levels in the three habitats. $24.56 \%$ and $24.00 \%$ of the EF$\mathrm{Pb}$ values in the supratidal wetlands of sites 1 and 3 are greater than 2 (Fig. 4), suggesting a certain degree of accumulation of $\mathrm{Pb}$ and potential ecological risks. By contrast, the EF-Pb values in the supratidal wetlands of sites 2 and 4 are less than 2 , indicating minimal enrichment levels. $64.00 \%$ and $62.07 \%$ of the EF-Zn values in the supratidal wetlands of sites 3 and 4 are greater than 2 (Fig. 4), suggesting that Zn has been enriched in the two habitats. The mean EF-Zn values in the supratidal wetlands of sites 1 and 2 are also greater than 2 (Fig. 4), but Zn has only been slightly enriched (i.e., $\mathrm{Zn}$ concentration has not yet reached the pollution level). The EFs with values greater than 2 in the supratidal wetlands of sites 1,2, 3, and 4 are $61.40 \%, 47.62 \%, 88.00 \%$, and $74.14 \%$ for As concentrations and $59.65 \%, 95.24 \%, 92.00 \%$, and $48.28 \%$ for Cd concentrations, respectively. The results suggest varying degrees of As and Cd accumulation and enrichment in the habitats along the west coast of Bohai Sea. 

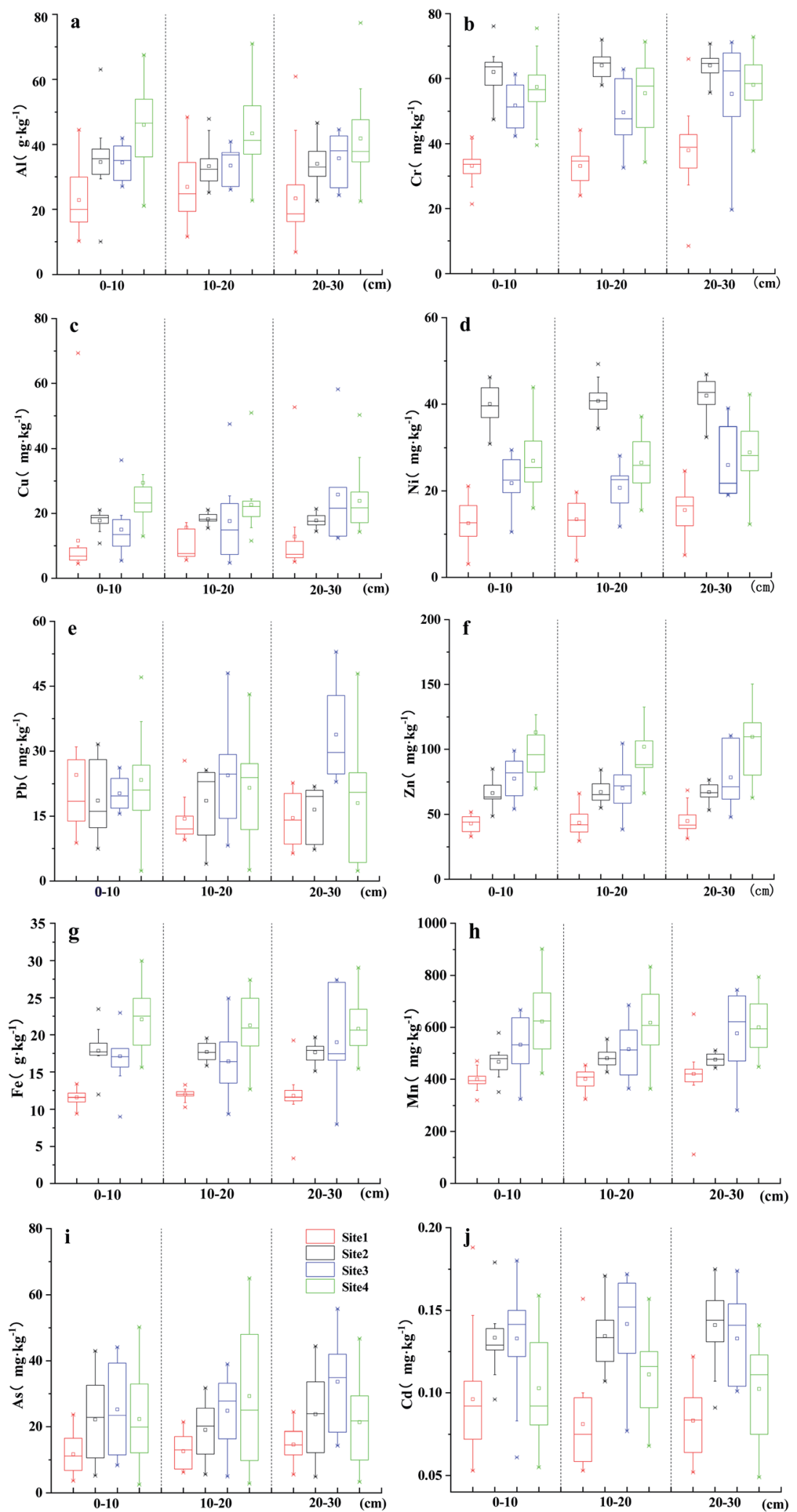

Fig. 3 Spatial distribution for soil heavy metals in the four supratial wetlands along the west coast of Bohai Sea.

Ecological RI is widely used to determine the ecological risk of heavy metals in soils and sediments. ${ }^{1,38}$ The RI of the supratidal wetland in site 1 is 57.27 , which is significantly lower than the RIs of the other supratidal wetlands (Fig. 5). According to the ecological risk assessment, the RIs of all study sites are less than 150, suggesting a low accumulation 


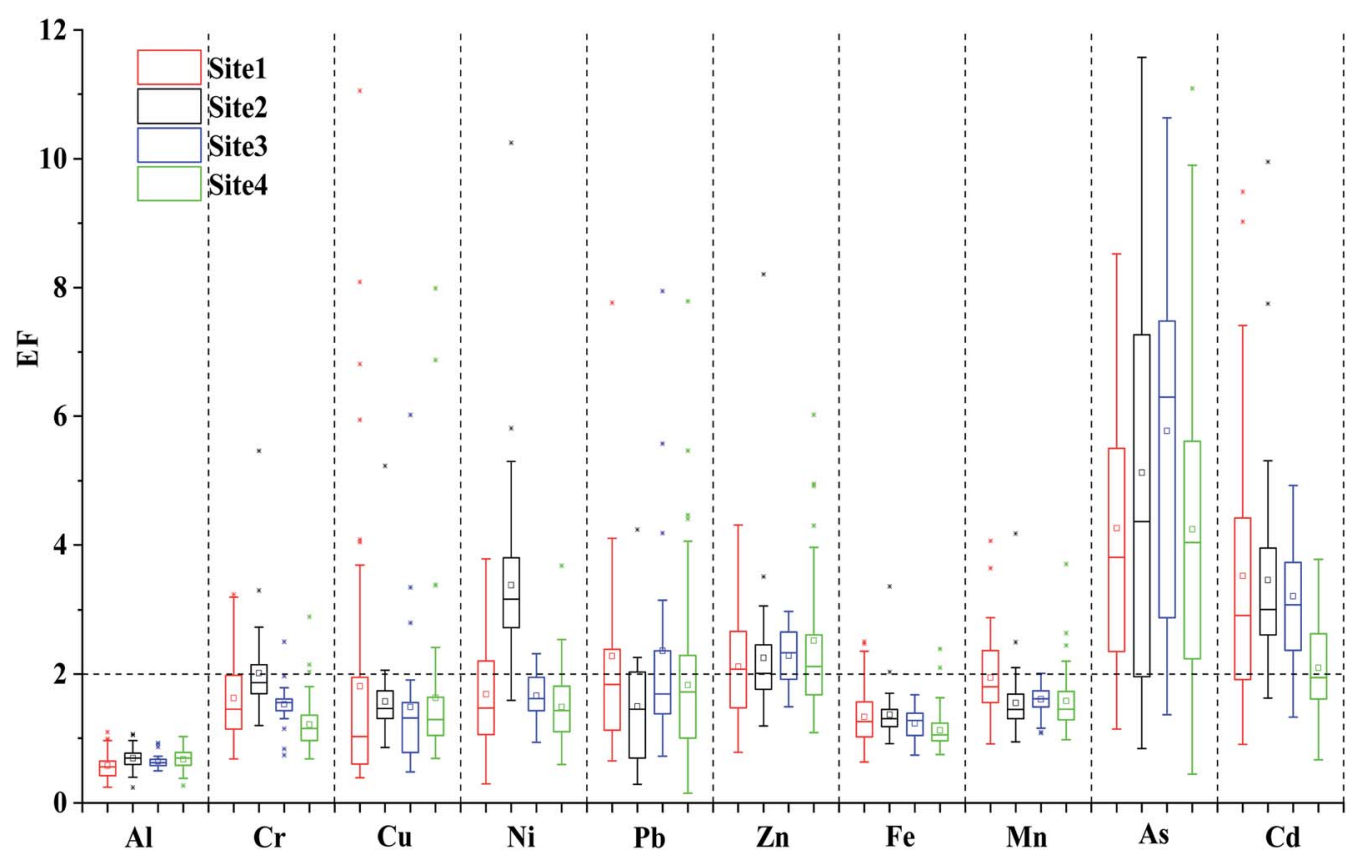

Fig. 4 Enrichment factors (EF) of heavy metals in the four supratidal wetlands along the west coast of Bohai Sea.

risk in the habitats. However, the values of RI are primarily dominated by the risk indices $\left(E_{\mathrm{r}}{ }^{i}\right)$ of As and Cd. The sums of the $E_{\mathrm{r}}{ }^{i}$-As and $E_{\mathrm{r}}{ }^{i}$-Cd of the supratidal wetlands of sites 1, 2, 3, and 4 are $45.27,63.49,78.03$, and 59.64, while the corresponding contribution percentages of the sums of $\mathrm{Cd}$ and As to the overall potential ecological risks are $79.05 \%, 77.80 \%$, $80.54 \%$, and $76.43 \%$. The result of the degree of contamination $\left(C_{\mathrm{d}}\right)$ of the supratidal wetland of site 1 is $6.86<8$ (Fig. 5), which is a low-risk state. While, the $C_{\mathrm{d}}$ values of the three other supratidal wetlands are higher than 8 , indicating moderate ecological risk. In this study, we use another contamination index of PN to evaluate the degree of heavy metals contamination, the result show that PN of the supratidal wetland of site 1 is 0.74 , which indicates that the level of heavy metals pollution in the soil is on the alert. However, the PN values of the three other supratidal wetlands lie between 1 and 2 (Fig. 5), indicating a low pollution risk. Regardless of the differences between $C_{\mathrm{d}}$ and PN, the accumulation risk of site 1 is lower than that of sites 2, 3 and 4 . This phenomenon may be due to the selected study area (site 1) having been surrounded by macrophanerophytes of Tamarix chinensis, which have a barrier function against heavy metals. However, the other three sites locate outside of the nature reserve area, which may have been influenced by the local industrial and agricultural development in these areas. For example, many agricultural and tourist facilities are found in the neighbouring regions of sites 2 and 3, as an impurity in phosphate ores, $\mathrm{Cd}$ is often found in phosphate fertilizers. ${ }^{39}$

\subsection{Correlation and homology analysis for heavy metals}

In general, those closely related heavy metals in soils may be homologous and come from similar sources. ${ }^{2}$ In this study, $\mathrm{Al}$, $\mathrm{Fe}, \mathrm{Mn}, \mathrm{Cr}$ and $\mathrm{Zn}$ in the supratidal wetland of site 1 are positively correlated with one another or multiple heavy metals (Table 2), suggesting that these metals might originated from common source. In addition, the conservative elements of $\mathrm{Al}$ and $\mathrm{Fe}$ are stable in the crust and often used as reference metals in many studies. ${ }^{2,40}$ Here, those strongly correlated metals of Al, Fe, Mn, Cr and $\mathrm{Zn}$ in site 1 are classified as one group (Fig. 6a), which might come from natural sources. However, $\mathrm{Cu}, \mathrm{Ni}, \mathrm{Pb}$, As and $\mathrm{Cd}$ are found no significant correlations with $\mathrm{Al}$, Fe and/ or Mn in site 1 (Table 2), which indicate that these heavy metals are affected by exogenous input factors.

Cluster analysis results show that the five elements of $\mathrm{Pb}, \mathrm{Cu}$, $\mathrm{Cd}$, As and Ni in site 1 are subdivided into three groups (Fig. 6a), which suggest that the exogenous heavy metals are complex in

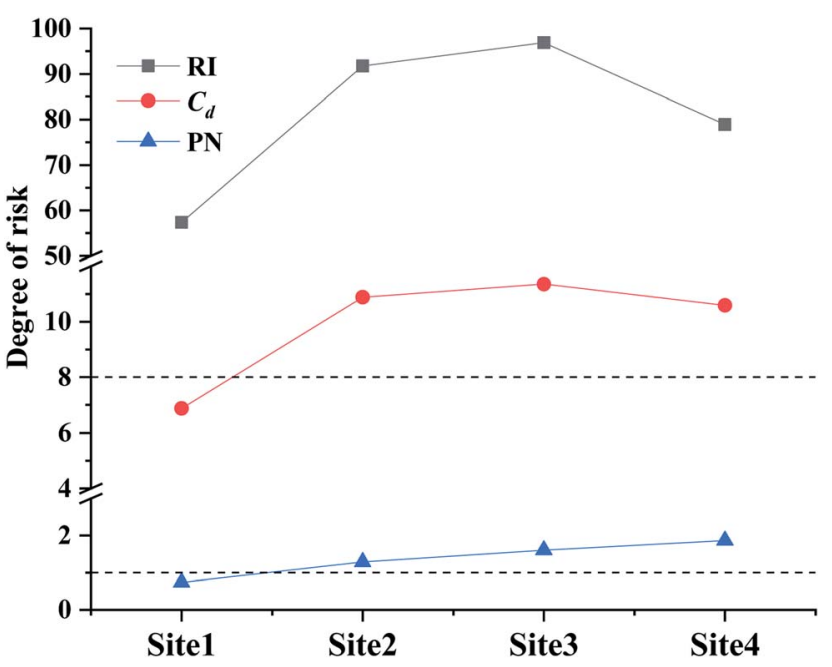

Fig. 5 Potential ecological risk index (RI) and degree of contamination $\left(C_{d}\right)$ in the four supratidal wetlands along the west coast of Bohai Sea. 
Table 2 Correlation analysis for heavy metals in the supratidal wetlands of site 1 and site 2 along the west coast of Bohai Sea ${ }^{a}$

\begin{tabular}{|c|c|c|c|c|c|c|c|c|c|c|}
\hline & $\mathrm{Al}$ & $\mathrm{Cr}$ & $\mathrm{Cu}$ & $\mathrm{Ni}$ & $\mathrm{Pb}$ & $\mathrm{Zn}$ & $\mathrm{Fe}$ & Mn & As & $\mathrm{Cd}$ \\
\hline $\mathrm{Al}$ & & 0.156 & -0.042 & -0.059 & 0.245 & 0.243 & $0.684^{* *}$ & $0.547 * *$ & 0.13 & -0.205 \\
\hline $\mathrm{Cr}$ & 0.29 & & 0.069 & $0.473^{* *}$ & -0.061 & $0.485^{* *}$ & $0.548^{* *}$ & $0.570^{* *}$ & 0.235 & 0.264 \\
\hline $\mathrm{Ni}$ & -0.20 & 0.16 & 0.09 & & 0.089 & 0.169 & 0.15 & 0.146 & $0.443^{* *}$ & 0.17 \\
\hline $\mathrm{Pb}$ & -0.25 & -0.30 & -0.42 & -0.36 & & 0.244 & 0.106 & 0.137 & -0.018 & -0.07 \\
\hline $\mathrm{Zn}$ & -0.16 & $0.571^{* *}$ & $0.630^{* *}$ & 0.23 & -0.28 & & $0.418^{* *}$ & $0.427 * *$ & -0.099 & 0.116 \\
\hline As & -0.21 & -0.01 & -0.15 & 0.07 & 0.28 & 0.28 & -0.25 & -0.06 & & 0.12 \\
\hline $\mathrm{Cd}$ & -0.02 & -0.01 & -0.04 & -0.06 & 0.18 & -0.03 & -0.09 & 0.05 & 0.21 & \\
\hline
\end{tabular}

${ }^{a}$ The upper triangular part of the matrix displays the correlation coefficients for heavy metals in site 1, while the lower triangular part indicates the correlation coefficients for heavy metals in site $2 .{ }^{*}$ Correlation is significant at the 0.05 level (2-tailed), ${ }^{* *}$ Correlation is significant at the 0.01 level $(2$ tailed).

their sources and input pathways. In the supratidal wetland of site 2, $\mathrm{Al}, \mathrm{Cr}$ and $\mathrm{Mn}$ have positive correlations with Fe (Table 2), suggesting that these heavy metals are homology and similarity in their sources..$^{41}$ Additionally, the cluster analysis results also support our deduction for those heavy metals in site 2 (Fig. 6b). In this study, $\mathrm{Cu}$ and $\mathrm{Zn}$ have no significant correlations with $\mathrm{Fe}$, but they are positively and significantly correlated with $\mathrm{Cr}$ and $\mathrm{Mn}$ in site 2 (Table 2). In some previous studies, Mn had been selected as a reference element due to its robust relationships with other heavy metals. ${ }^{25,29} \mathrm{Thus}, \mathrm{Cu}$ and $\mathrm{Zn}$ in site 2 may have similar sources with Mn. However the cluster analysis have shown that the two heavy metals belonging to different categories (Fig. 6b). Ni, As and Cd have no significant correlations with other heavy metals (Table 2), indicating that the three kinds of heavy metals may be influenced by unpredictable exogenous input. In most cases, these heavy metals might come from atmospheric deposition, wastewater discharge and/or agricultural activities. ${ }^{19}$

In this study, $\mathrm{Cr}, \mathrm{Cu}, \mathrm{Ni}, \mathrm{Zn}, \mathrm{Fe}$ and $\mathrm{Mn}$ are positively and significantly correlated with $\mathrm{Al}$ in site 3 (Table 3), indicating that those heavy metals are less affected by external input factors. ${ }^{29} \mathrm{~Pb}$, As and $\mathrm{Cd}$ have no significant correlations with $\mathrm{Al}$ and $\mathrm{Fe}$ in site 3, they may come from different sources and develop without affecting each other. The cluster analysis show that the classification of the ten heavy metals is consistent with the correlation result (Fig. 6c). In the supratidal wetland of site 4 , all heavy metals except $\mathrm{Cd}$ are positively and significantly correlated with Al, Fe and/or Mn (Table 3), which
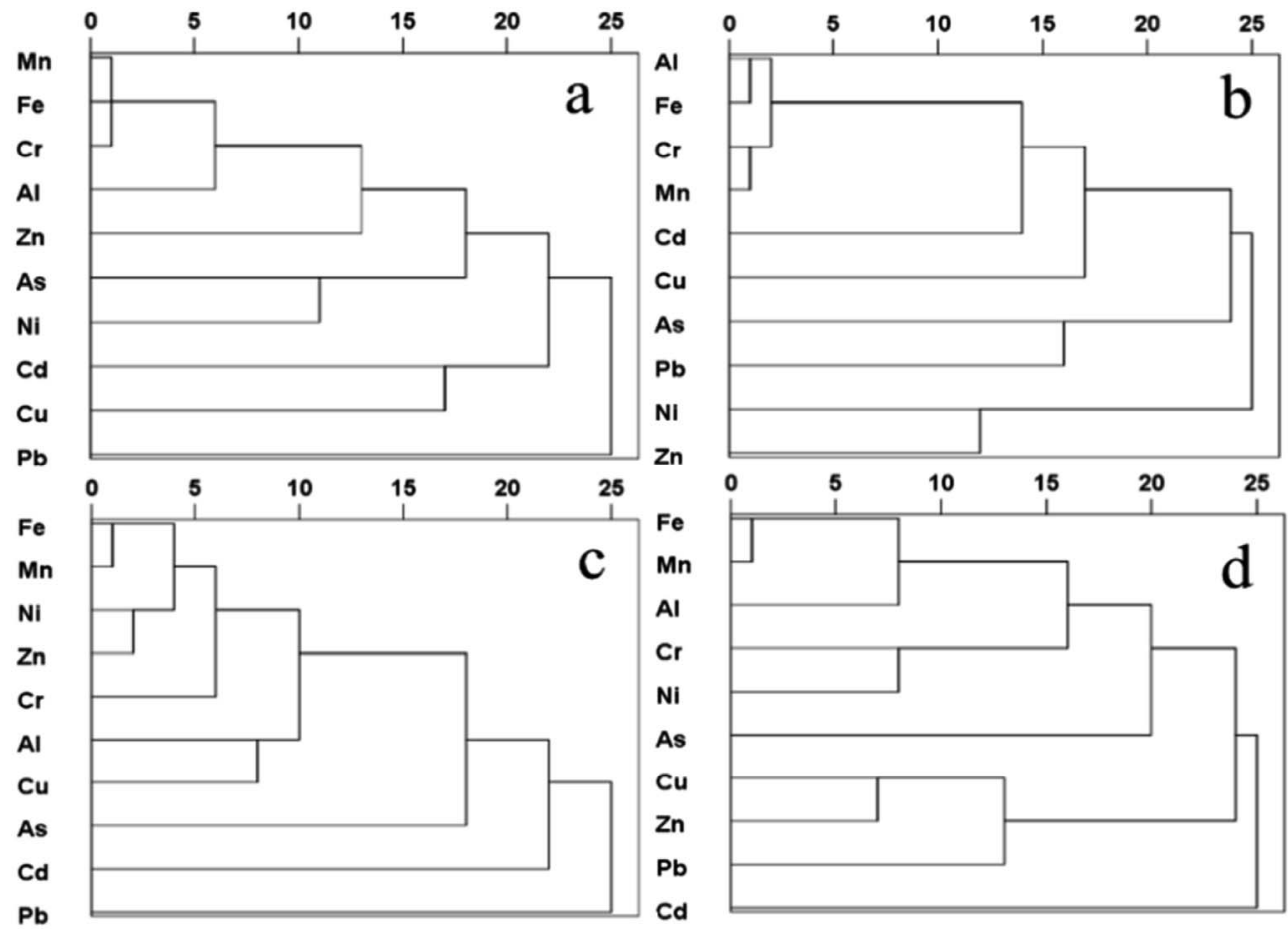

Fig. 6 Cluster analysis for heavy metals in the four supratidal wetlands along the west coast of Bohai Sea. (a) Site 1; (b) site 2; (c) site 3; (d) site 4. 
Table 3 Correlation analysis for heavy metals in the supratidal wetlands of site 3 and site 4 along the west coast of Bohai Sea ${ }^{a}$

\begin{tabular}{|c|c|c|c|c|c|c|c|c|c|c|}
\hline & $\mathrm{Al}$ & $\mathrm{Cr}$ & $\mathrm{Cu}$ & $\mathrm{Ni}$ & $\mathrm{Pb}$ & $\mathrm{Zn}$ & $\mathrm{Fe}$ & $\mathrm{Mn}$ & As & $\mathrm{Cd}$ \\
\hline $\mathrm{Al}$ & & $0.622 * *$ & $0.506 * *$ & $0.737 * *$ & 0.075 & $0.689^{* *}$ & $0.681 * *$ & $0.775 * *$ & 0.31 & 0.25 \\
\hline $\mathrm{Cr}$ & 0.241 & & $0.410^{*}$ & $0.723 * *$ & -0.024 & $0.621^{* *}$ & $0.788 * *$ & $0.762 * *$ & 0.18 & 0.16 \\
\hline $\mathrm{Ni}$ & 0.02 & $0.661 * *$ & $0.408 * *$ & & -0.059 & $0.800^{* *}$ & $0.715^{* *}$ & $0.695^{* *}$ & 0.20 & 0.37 \\
\hline $\mathrm{Pb}$ & 0.061 & 0.215 & $0.392 * *$ & 0.118 & & -0.319 & -0.013 & 0.154 & -0.10 & $-0.472^{*}$ \\
\hline Zn & 0.113 & $0.494^{* *}$ & $0.672^{* *}$ & $0.553 * *$ & $0.329 *$ & & $0.704 * *$ & $0.621 * *$ & 0.30 & $0.566^{* *}$ \\
\hline As & $0.398 * *$ & 0.14 & 0.18 & 0.012 & 0.05 & 0.17 & $0.464^{* *}$ & $0.457^{* *}$ & & -0.01 \\
\hline $\mathrm{Cd}$ & 0.08 & 0.18 & 0.14 & 0.183 & 0.05 & 0.19 & 0.19 & 0.18 & -0.05 & \\
\hline
\end{tabular}

${ }^{a}$ The upper triangular part of the matrix displays the correlation coefficients for heavy metals in site 3, while the lower triangular part indicates the correlation coefficients for heavy metals in site $4 .{ }^{*}$ Correlation is significant at the 0.05 level (2-tailed), **Correlation is significant at the 0.01 level (2tailed).

indicate that these heavy metals have similar sources or they are affected by the same factors. ${ }^{41}$ However, the cluster analysis result show that all heavy metals are classified into four categories (Fig. 6d), which indicate that $\mathrm{Cd}, \mathrm{Zn}, \mathrm{Cu}, \mathrm{Pb}$ and $\mathrm{As}$ have different sources with $\mathrm{Al}, \mathrm{Cr}, \mathrm{Mn}, \mathrm{Fe}$ and $\mathrm{Ni}$ in spite of their correlations. In this study, other quantitative ecological method, such as PCA, should be used to explore the sources and input pathways of heavy metals.

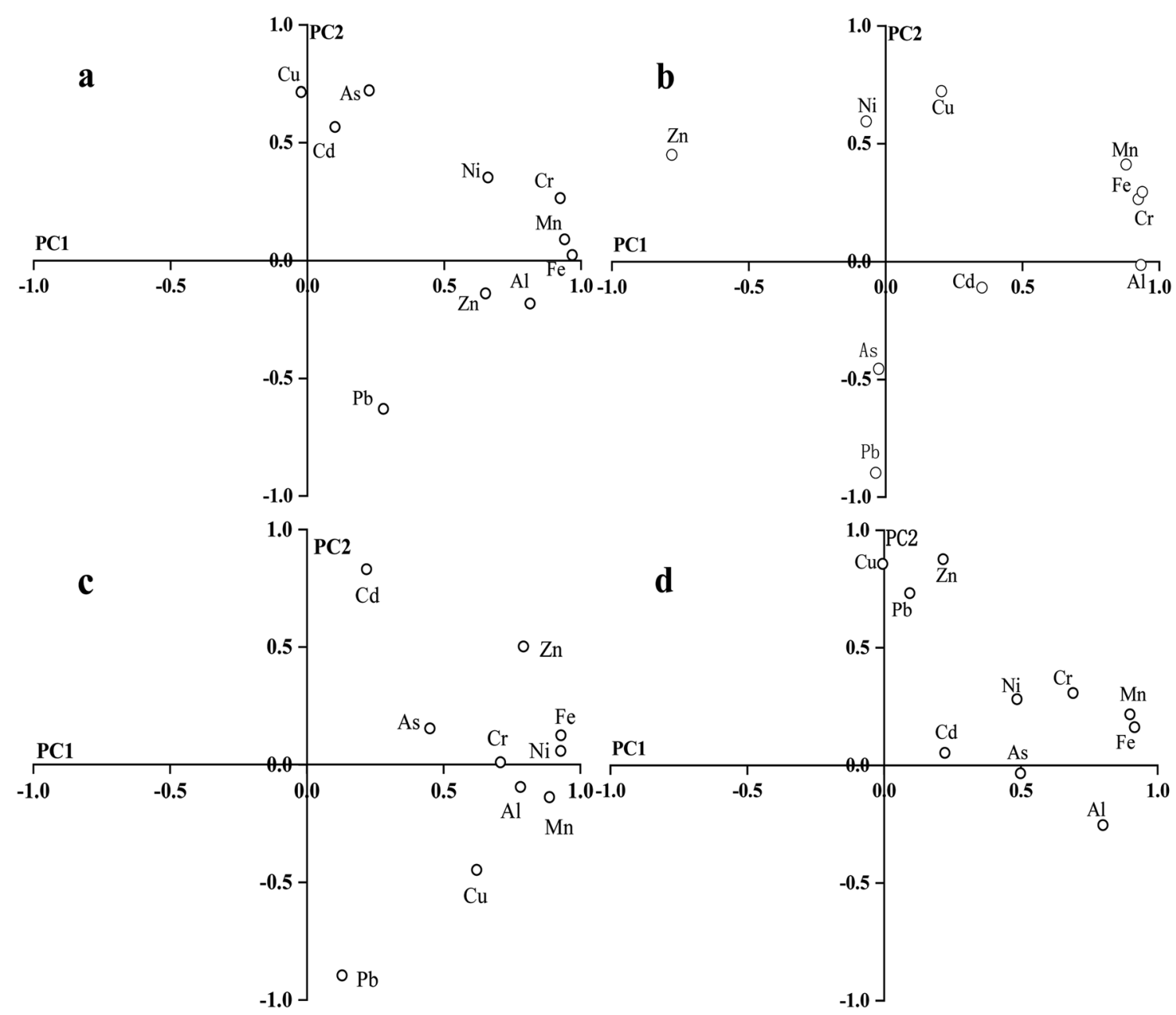

Fig. 7 Principal component analysis (PCA) for heavy metals in the four supratidal wetlands along the west coast of Bohai Sea. (a) Site 1; (b) site 2; (c) site 3; (d) site 4 


\subsection{Sources of heavy metals}

Two principle components (PCs) can explain $63.42 \%$ of the total variance in the supratidal wetland of site 1 . In particular, PC1 and PC2 can explain $43.93 \%$ and $19.49 \%$ of the total variance, respectively (Table S1†). Fang et al. ${ }^{42}$ and Jiao et al. ${ }^{43}$ have suggested that PC1 of the biplot is likely correlated with natural factors. In the present research, PC1 is strongly and positively correlated with $\mathrm{Al}, \mathrm{Cr}, \mathrm{Fe}, \mathrm{Ni}, \mathrm{Zn}$, and Mn (Fig. 7a), which indicate that the sources of these heavy metals may have originated from natural sources. Additionally, the heavy metals of $\mathrm{Cr}, \mathrm{Fe}, \mathrm{Zn}$, and $\mathrm{Mn}$ in site 1 are positively correlated with soil $\mathrm{P}$, but no significant correlations with soil $\mathrm{N}$ and $\mathrm{pH}$ (Fig. 8a) have been established. Therefore, $\mathrm{Al}, \mathrm{Cr}, \mathrm{Fe}, \mathrm{Zn}$, and $\mathrm{Mn}$ may have primarily originated from parent materials because $\mathrm{P}$ is a rockderived element of the earth's crust. ${ }^{44}$ A significant correlation is found between $\mathrm{Ni}$ and soil $\mathrm{N}$ (Fig. 8a), which suggests that $\mathrm{Ni}$ originates from nitrogen deposition. PC2 represents the anthropogenic activities and relevant factors reported in many studies. ${ }^{17,42,43}$ In the present study, PC2 is positively correlated with $\mathrm{Cu}, \mathrm{Cd}$, and As. However, these heavy metals are not correlated with the physicochemical properties of the soil samples, and we suppose that these heavy metals may have primarily originated from the emissions of nearby factories. PC2 is negatively correlated with $\mathrm{Pb}$, which suggests that $\mathrm{Pb}$ may have originated from other anthropogenic activities other than industrial sources. Our finding further indicates that $\mathrm{Pb}$ may have originated from embankment constructions or from gasoline and diesel combustion related to agricultural machineries.

As for the supratidal wetland of site 2, the first two PCs can explain $65.90 \%$ of the total variance (Table S2 $\dagger$ ). PC1 $(43.60 \%)$ is positively correlated with $\mathrm{Al}, \mathrm{Cr}, \mathrm{Fe}$, and $\mathrm{Mn}$ (Fig. 7b). Given that $\mathrm{Al}$ is a geological element in the earth's crust, ${ }^{2}$ we conclude that the heavy metals of $\mathrm{Al}, \mathrm{Cr}, \mathrm{Fe}$, and $\mathrm{Mn}$ may have mainly originated from the weathering of parent materials. PC1 is positively related to $\mathrm{Cd}$ but not conspicuously as showing of $\mathrm{Al}$ and $\mathrm{Fe}$ (Fig. 7b), indicating sources differentiation. Here, Cd may have mainly originated from atmospheric deposition. PC2 $(22.30 \%)$ is positively correlated with $\mathrm{Cu}$ and $\mathrm{Ni}$ (Fig. 7b), implying that these two heavy metals are related to anthropogenic activities in the habitat. $\mathrm{Cu}$ is positively correlated with soil $\mathrm{P}$ but negatively correlated with salinity (Fig. 8b), indicating that $\mathrm{Cu}$ and Ni may have originated from agricultural activities (wetland reclamation and/or phosphate fertilizers). As and $\mathrm{Pb}$ are negatively correlated with PC2, but no significant correlations are found between these two heavy metals and the physio-chemical properties of their soils (Fig. 7b and 8b). Anthropogenic activities, such as automobile exhaust, industry exhaust, and port

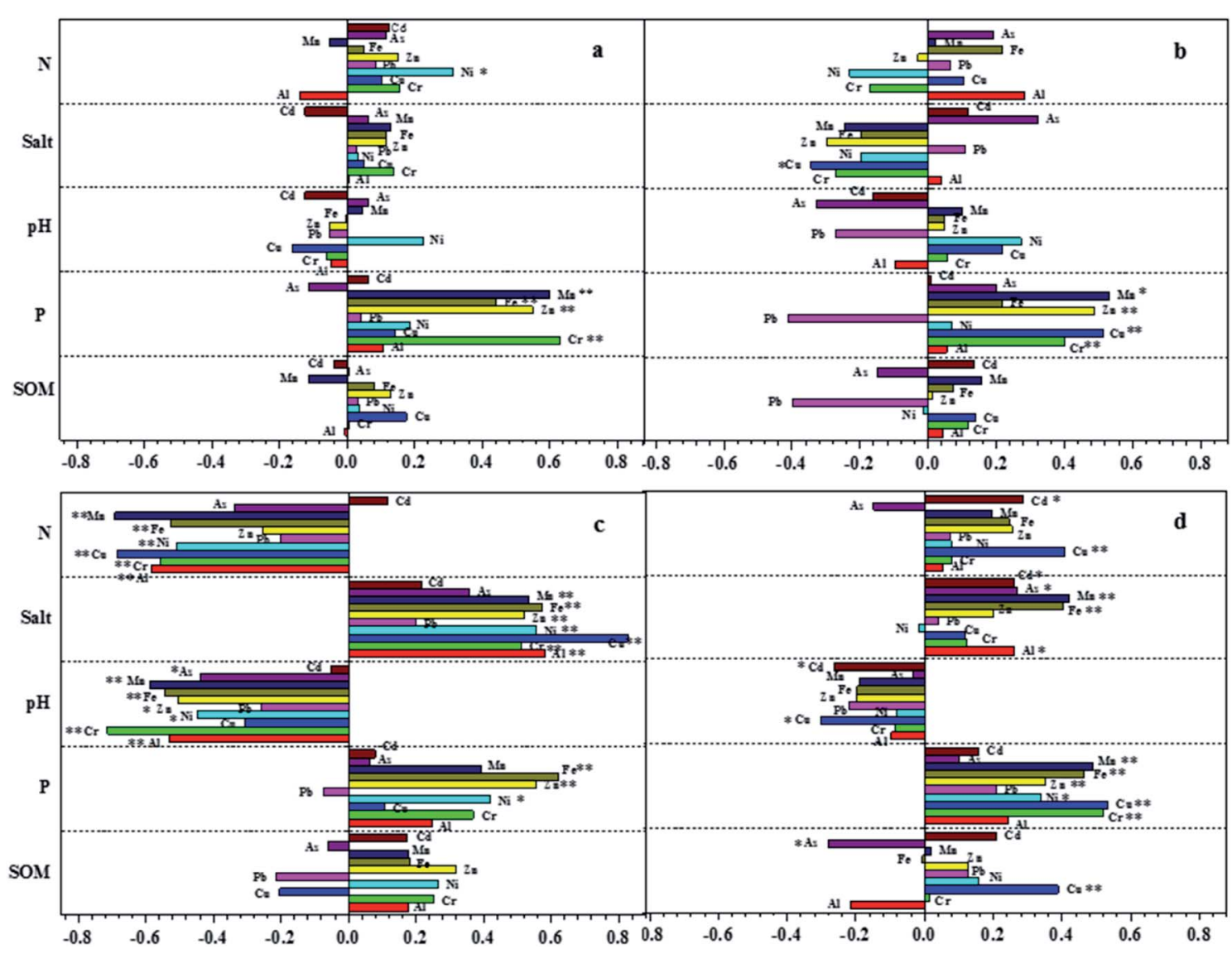

Fig. 8 Correlation coefficients between heavy metals and soil physicochemical properties in the four supratidal wetlands along the west coast of Bohai Sea. (a) Site 1; (b) site 2; (c) site 3; (d) site $4 .{ }^{*}$ correlation is significant at the 0.05 level (2-tailed), ** correlation is significant at the 0.01 level (2-tailed). 
construction, may have been the sources of $\mathrm{As}$ and $\mathrm{Pb}$ in the habitat. Zn lies between PC1 and PC2 (Fig. 7b), implying that Zn is influenced by anthropogenic activities and natural factors. However, $\mathrm{Zn}$ is somewhat close to the PC1 axis $(-0.781)$. Soil P is positively correlated with $\mathrm{Zn}$ (Fig. 8b), suggesting that $\mathrm{Zn}$ has mainly originated from acid deposition (phosphoric acid).

As for the supratidal wetland of site 3 , the first two PCs can explain $69.17 \%$ of the total variance (Table S3†). PC1 $(49.22 \%)$ is positively correlated with $\mathrm{Al}, \mathrm{Cr}, \mathrm{Fe}, \mathrm{Ni}$, and $\mathrm{Mn}$ (Fig. 7c). The heavy metals of $\mathrm{Cr}, \mathrm{Ni}$, and $\mathrm{Fe}$ are positively correlated with soil P but negatively correlated with soil N (Fig. 8c), which suggest that parent materials are the major sources of $\mathrm{Al}, \mathrm{Cr}, \mathrm{Fe}, \mathrm{Ni}$, and Mn in this habitat. ${ }^{45}$ PC1 is closely related with As and Zn but not with $\mathrm{Al}$ and $\mathrm{Fe}$ (Fig. 7c). The negative correlation of As and Zn with soil pH (Fig. 8c) suggests that the heavy metals may have originated from atmospheric acid deposition. $\mathrm{Cu}$ lies between the two axes of PC1 and PC2 but much closer to the $\mathrm{PC} 1$ axis (0.621). $\mathrm{Cu}$ is positively correlated with $\mathrm{Al}, \mathrm{Cr}, \mathrm{Fe}, \mathrm{Ni}$, and $\mathrm{Mn}$ (Fig. 7c), suggesting that $\mathrm{Cu}$ may have originated from rock weathering or the parent materials of soil in this habitat. PC2 (19.95\%), which can be defined as the anthropogenic factors in site 3 , is positively correlated with Cd but negatively correlated with $\mathrm{Pb}$ (Fig. 7c). We suppose that $\mathrm{Pb}$ and $\mathrm{Cd}$ are mainly related to the different human activities. Combined with the actual situations in the wetland, we suggest that Cd may be associated with the emissions of existing or historical industries, and $\mathrm{Pb}$ may have originated from vehicle exhausts (e.g., tourist buses and engineering vehicles). ${ }^{46}$

As for the supratidal wetland of site 4 , the first two PCs can explain $57.11 \%$ of the total variance (Table S4 $\dagger$ ). PC1 $(37.48 \%$ ) is positively correlated with $\mathrm{Al}, \mathrm{Cr}, \mathrm{Fe}, \mathrm{Ni}$, and $\mathrm{Mn}$ (Fig. 7d), and all heavy metals in addition to $\mathrm{Al}$ are positively correlated with soil $\mathrm{P}$ (Fig. 8d), suggesting that $\mathrm{Cr}, \mathrm{Fe}, \mathrm{Ni}$, and $\mathrm{Mn}$ in this habitat not only originate from parent materials but also from atmospheric acid deposition (phosphoric acid). ${ }^{\mathbf{4 7 , 4 8}}$ As and Cd are closely related to PC1 (Fig. 7d), and Cd is positively correlated with $\mathrm{N}$ (Fig. 8d), suggesting that As and Cd may have originated from atmospheric acid deposition (nitric acid). ${ }^{49}$ PC2 (19.64\%) is positively correlated with $\mathrm{Cu}, \mathrm{Zn}$, and $\mathrm{Pb}$ in this habitat (Fig. 7d). Given that $\mathrm{Cu}$ is positively correlated with SOM, soil N, and $\mathrm{P}$ (Fig. $8 \mathrm{~d}$ ), we conclude that $\mathrm{Cu}, \mathrm{Zn}$, and $\mathrm{Pb}$ are likely controlled by wetland reclamation and agricultural activities (e.g., fertilization and sewage water irrigation).

\section{Conclusion}

The distribution and accumulation risk of heavy metals are higher in the middle and northern regions than in the southern region along the west coast of Bohai Sea. The ecological RIs of all heavy metals indicate that As and $\mathrm{Cd}$ are the most widespread pollutants among the heavy metals in the rainfall-driven supratidal wetlands of Bohai Sea. The source analysis of all habitats suggests that $\mathrm{Al}, \mathrm{Cr}, \mathrm{Mn}$, and $\mathrm{Fe}$ mainly originate from soil parent materials and rock weathering. Thus, these heavy metals can be neglected in the formulation of environmental protection policies and monitoring programs. $\mathrm{Pb}$ is closely related to human activities in the coastal area of Bohai Sea, and the major focuses should be on the waste discharge of $\mathrm{Pb}$ related enterprises, the transportation industry, and the overdevelopment of agricultural activities. $\mathrm{Cu}, \mathrm{Cd}$, and $\mathrm{As}$ can be attributed to human activities, and they may also be related to atmospheric deposition. Hence, we should also pay attention to the waste discharge of related enterprises and the overdevelopment of agricultural activities. Furthermore, the heavy metals of $\mathrm{Cu}, \mathrm{Cd}$, and As in the atmosphere should be supervised and monitored. $\mathrm{Ni}$ and $\mathrm{Zn}$ are correlated with human activities in some habitats and may have originated from soil parent materials or atmospheric deposition in other habitats. Appropriate measures should be taken according to the actual conditions in the coastal wetlands.

\section{Conflicts of interest}

There are no conflicts to declare.

\section{Acknowledgements}

This work is financially supported by National Natural Science Foundation of China (41303057), Tianjin Research Program of Application Foundation and Advanced Technology (14JCYBJC23000), and Training Program for Innovative Research Team in Tianjin Institutions of Higher Education (TD13-5021).

\section{References}

1 J. Bai, R. Xiao, B. Cui, K. Zhang, Q. Wang, X. Liu, H. Gao and L. Huang, Assessment of Heavy Metal Pollution in Wetland Soils from the Young and Old Reclaimed Regions in the Pearl River Estuary, South China, Environ. Pollut., 2011, 159, 817-824.

2 J. Bai, R. Xiao, Q. Zhao, Q. Lu, J. Wang and K.-R. Reddy, Seasonal Dynamics of Trace Elements in Tidal Salt Marsh Soils as Affected by the Flow-Sediment Regulation Regime, PLoS One, 2014, 9, e107738.

3 M. Thangavelu and D. J. Bagyaraj, Use of Arbuscular Mycorrhizal Fungi in Phytoremediation of Heavy Metal Contaminated Soils, Proc. Natl. Acad. Sci. U. S. A., 2012, 80, 103-121.

4 W. Ren, Y. Geng, Z. Ma, L. Sun, B. Xue and T. Fujita, Reconsidering Brownfield Redevelopment Strategy in China's Old Industrial Zone: A Health risk Assessment of Heavy Metal Contamination, Environ. Sci. Pollut. Res., 2014, 22, 2765-2775.

5 G. Zhang, J. Bai, Q. Zhao, Q. Lu, J. Jia and X. Wen, Heavy Metals in Wetland Soils along a Wetland-forming Chronosequence in the Yellow River Delta of China: Levels, Sources and Toxic Risk, Ecol. Indic., 2016, 69, 331-339.

6 A. Pejman, G.-N. Bidhendi, M. Ardestani, M. Saeedi and B. Akbar, A new index for assessing heavy metals contamination in sediments: a case study, Ecol. Indic., 2015, 58, 365-373.

7 M. Mohamed, M. Saddik, M. Maanan, C. Mohamed, A. Omar and B. Zourarah, Environmental and ecological risk 
assessment of heavy metals in sediments of Nador lagoon, Morocco, Ecol. Indic., 2015, 48, 616-626.

8 G. Guo, F. Wu, F. Xie and R. Zhang, Spatial distribution and pollution assessment of heavy metals in urban soils from southwest China, J. Environ. Sci., 2012, 24(3), 410-418.

9 H. Yu, S. Ni, Z. He, C. Zhang, X. Nan, B. Kong and Z. Weng, Analysis of the spatial relationship between heavy metals in soil and human activities based on landscape geochemical interpretation, J. Geochem. Explor., 2014, 146, 136-148.

10 Y. Yin, C. A. Impellitteri, S.-J. You and H. E. Allen, The importance of organic matter distribution and extract soil: solution ratio on the desorption of heavy metals from soils, Sci. Total Environ., 2002, 287(1-2), 107-119.

11 G. Du Laing, J. Rinklebe, B. Vandecasteele, E. Meers and F. M. G. Tack, Trace Metal Behaviour in Estuarine and Riverine Floodplain Soils and Sediments: A Review, Sci. Total Environ., 2009, 407, 3972-3985.

12 S. S. S Lau and L. M Chu, The significance of sediment contamination in a coastal wetland, Hong Kong, China, Water Res., 2000, 34(2), 379-386.

13 P.-K. Rai and B. D. Tripathi, Heavy metals in Industrial Wastewater, Soil and Vegetables in Lohta Village, India, Toxicol. Environ. Chem., 2008, 90, 247-257.

14 A. Guittonny-Philippe, V. Masotti, P. Höhener, J.-L. Boudenne, J. Viglione and I. Laffont-Schwob, Constructed wetlands to reduce metal pollution from industrial catchments in aquatic Mediterranean ecosystems: a review to overcome obstacles and suggest potential solutions, Environ. Int., 2014, 64, 1-16.

15 F. Wang and A. Tessier, Zero-valent sulfur and metal speciation in sediment porewaters of freshwater lakes, Environ. Sci. Technol., 2009, 43(19), 7252-7257.

16 R.-A. Düring, T. Hoß and S. Gäth, Sorption and Bioavailability of Heavy Metals in Long-term Differently Tilled Soils Amended with Organic Wastes, Sci. Total Environ., 2003, 313, 227-234.

17 J. Bai, Z. Yang, B. Cui, H. Gao and Q. Ding, Some heavy metals distribution in wetland soils under different land use types along a typical plateau lake, China, Soil Tillage Res., 2010, 106(2), 344-348.

18 R. Xiao, J. Bai, Q. Lu, Q. Zhao, Z. Gao, X. Wen and X. Liu, Fractionation, Transfer, and Ecological Risks of Heavy Metals in Riparian and Ditch Wetlands across a 100-Year Chronosequence of Reclamation in an Estuary of China, Sci. Total Environ., 2015, 517, 66-75.

19 M. A. M. Abdallah, Ecological risk assessment of heavy metals from the surficial sediments of a shallow coastal lagoon, Egypt, Environ. Technol., 2011, 32(9), 979-988.

20 X. Chen, X. Xia, Y. Zhao and P. Zhang, Heavy metal concentrations in roadside soils and correlation with urban traffic in Beijing, China, J. Hazard. Mater., 2010, 181(1-3), 640-646.

21 J. Bai, R. Xiao, K. Zhang and H. Gao, Arsenic and heavy metal pollution in wetland soils from tidal freshwater and salt marshes before and after the flow-sediment regulation regime in the Yellow River Delta, China, J. Hydrol., 2012, 450, 244-253.
22 R. M. Cenci and J.-M. Martin, Concentration and fate of trace metals in Mekong River Delta, Sci. Total Environ., 2004, 332(1-3), 167-182.

23 J. Bai, Q. Zhao, Q. Lu, J. Wang and K. RameshReddy, Effects of Freshwater Input on Trace Element Pollution in Salt Marsh Soils of a Typical Coastal Estuary, China, J. Hydrol., 2015, 520, 186-192.

24 G. Han, X. Chu, Q. Xing, D. Li, J. Yu, Y. Luo, G. Wang, P. Mao and R. Rafique, Effects of episodic flooding on the net ecosystem $\mathrm{CO}_{2}$ exchange of a supratidal wetland in the Yellow River Delta, J. Geophys. Res.: Biogeosci., 2015, 120, 1506-1520.

25 F. Liu, S. Zhang, Y. Dong, Y. Zheng, D. Li and M. Wang, The Distribution and Enrichment of Trace Metals in the RainfallDriven Supratidal Wetlands of Tianjin, Clean: Soil, Air, Water, 2017, 45(12), 1700200.

$26 \mathrm{H}$. Wang, L. Chen, S. Hu and Z. Sun, The concentration distribution and evaluation of the heavy metals in the surface sediments of western Bohai Bay, Geophys. Geochem. Explor., 2016, 40(3), 609-613.

27 S. Bao, Soil Agro-chemistrical Analysis, China Agriculture Press, 2000, Beijing.

28 China National Environmental Monitoring Center (CNEMC), Chinese Elemental Background Values for Soils, Chinese Environmental Science Press, 1990, Beijing.

29 A. Jamshidi-Zanjani and M. Saeedi, Metal pollution assessment and multivariate analysis in sediment of Anzali international wetland, Environ. Earth Sci., 2013, 70(40), 1791-1808.

30 J. Li, L. Pu, Q. Liao, M. Zhu, X. Dai, Y. Xu, L. Zhang, H. Ming and Y. Jin, How anthropogenic activities affect soil heavy metal concentration on a broad scale: a geochemistry survey in Yangtze River Delta, Eastern China, Environ. Earth Sci., 2015, 73, 1823-1835.

31 L. Hakanson, An Ecological Risk Index for Aquatic Pollution Control- A Sedimentological Approach, Water Res., 1980, 14(8), 975-1001.

32 H. Zhang, Z. Wang, Y. Zhang, M. Ding and L. Li, Identification of traffic-related metals and the effects of different environments on their enrichment in roadside soils along the Qinghai-Tibet highway, Sci. Total Environ., 2015, 521-522, 160-172.

33 X. Wen, J. Bai, J. Jia, Z. Gao, J. Wang, Q. Lu and Q. Zhao, Contents of Heavy Metals and Their Sources in the Soils of Typical Intertidal Salt Marshes in the Yellow River Delta, Wetland Science, 2015, 13(6), 722-727.

34 Y. Zheng, M. Gao, S. Liu, J. Zhao, F. Guo and C. Wang, Distribution patterns and ecological assessment on heavy metals in the surface sediments of Laizhou Bay, Mar. Environ. Sci., 2015, (03), 354-360.

35 X. Meng, H. Zhang, B. Shan and J. Li, Pollution and Ecological Risk Assessment of Heavy Metals in Surface Sediment of the Duliujian River Drainage Basin, Urban Environ. Urban Ecol., 2016, 29(6), 36-41.

36 J. Bai, L. Huang, H. Gao and G. Zhang, Wetland biogeochemistry and ecological risk assessment, Phys. Chem. Earth, Parts A/B/C, 2017, 97, 1-2. 
37 P. W. Swarzensk, M. Baskaran, R. J. Rosenbauer and W. H. Orem, Historical trace element distribution in sediments from the Mississippi River delta, Estuaries Coasts, 2006, 29(6), 1094-1107.

$38 \mathrm{~J}$. Wu and Y. Li, Environment geochemistry of some heavy metals in the sediments of Bohai Bay, J. Oceanol. Limnol., 1985, 16(2), 92-101.

39 J. L. Han, F. S. Jin and K. Egashira, Environmental Impact Assessment of Tea Garden Soils by the Heavy Metal Concentration in Yantai City of Shandong Province, China, J. Fac. Agric., Kyushu Univ., 2007, 52(1), 135-139.

40 R. Ravisankar, S. Sivakumar, A. Chandrasekaran, K. V. Kanagasabapathy, M. V. R. Prasad and K. K. Satapathy, Statistical assessment of heavy metal pollution in sediments of east coast of Tamilnadu using Energy Dispersive X-ray Fluorescence Spectroscopy (EDXRF), Appl. Radiat. Isot., 2015, 102, 42-47.

41 X. Liu, X. Jiang, Q. Liu, A. Teng and W. Xu, Distribution and pollution assessment of heavy metals in surface sediments in the central Bohai Sea, China: a case study, Environ. Earth Sci., 2016, 75, 364.

42 S. B. Fang, X. B. Jia, X. Y. Yang, Y. D. Li and S. Q. An, A method of identifying priority spatial patterns for the management of potential ecological risks posed by heavy metals, J. Hazard. Mater., 2012, 237-238, 290-298.
43 W. Jiao, W. Ouyang, F. Hao, F. Wang and B. Liu, Long-Term Cultivation Impact on the Heavy Metal Behavior in a Reclaimed Wetland, Northeast China, J. Soils Sediments, 2014, 14, 567-576.

44 T. W. Walter and J. K. Syers, The fate of phosphorus during pedogenesis, Geoderma, 1976, 15(1), 1-19.

45 F. Jing, X. Chen, Z. Yang and B. Guo, Heavy metals status, transport mechanisms, sources, and factors affecting their mobility in Chinese agricultural soils, Environ. Earth Sci., 2018, 77(3), 104.

46 N. Hu, J. Liu, P. Huang, S. Yan, X. Shi and D. Ma, Sources, geochemical speciation, and risk assessment of metals in coastal sediments: a case study in the Bohai Sea, China, Environ. Earth Sci., 2017, 76(8), 309.

47 L. Luo, Y. Ma, S. Zhang, D. Wei and Y.-G. Zhu, An inventory of trace element inputs to agricultural soils in China, $J$. Environ. Manage., 2009, 90(8), 2524-2530.

48 H. Liu, Y. Zhang, X. Zhou, X. You, Y. Shi and J. Xu, Source identification and spatial distribution of heavy metals in tobacco-growing soils in Shandong province of China with ultivariate and geostatistical analysis, Environ. Sci. Pollut. Res., 2017, 24(6), 5964-5975.

49 X. Duan and Y. Li, Distributions and sources of heavy metals in sediments of the Bohai Sea, China: a review, Environ. Sci. Pollut. Res., 2017, 24(1), 24753-24764. 